\title{
Public Financing in Higher Education Institutions : Issues and Challenges
}

\author{
Shatrughan Prasad Gupta
}

Ph.D Scholar

Graduate School of Education, TU

\begin{abstract}
This paper is an attempt to analyze the present pattern of funding higher education in Nepal and to discuss the desirability and feasibility of various alternative methods of funding the same. Before federal system, higher education (HE) in Nepal was a state funded but currently the paradigm has been shifted to the province government besides the funding of central university, which has not been well-defined. Higher education itself benefits not only society at large, but also individuals, and as it attracts relatively more privileged sections of the society, there is a rationale for shifting the financial burden to the social domain rather to government sector alone.
\end{abstract}

The main objective is to review the current policies, practices of financing in promoting access, quality, relevancy, equity and prosperity. On the basis of secondary sources of data this paper focused the reports published by University Grants Commission, Nepal (UGC).Some other relevant literature, reports, articles, books, policy documents were critically analyzed and reviewed to draw the findings and conclusion. Some statistical methods were used for interpretation.

Resource constraints, equity, financing HE mostly from the general tax revenue may not be a desirable policy in the long run. Accordingly some of the alternative policy choices are discussed for financing HE from the public exchequer, student loans, student fees, and the role of the community investment. Among the available alternatives, it is argued that a discriminatory pricing mechanism and subsidy policies to community campuses of different layers of government would be relatively more efficient and equitable mechanism of financing as community campuses are providing the major access, equity, quality as well and reducing the financial burden of government with the cost recovery modality.

It is argued that such institutions should be the priority of government for promoting equitable quality access to HE with nominal costs of users.

Keywords: Goods, Revenue, Equity, Efficiency, Accountability, Relevancy, Quality, Cost-recovery, and etc. 


\section{Introduction}

There has been a debate on the issue that higher education (HE) is the public goods or it is the private goods (Williams, 2016). In this paper, an attempt has been done to analyze it with various prospective and link them with social goods. Community campuses are social entrepreneur as it has been established for non profit making organization by people initiative from the beginning of the history of higher education Nepal, which generates a positive change in the society. So, treated HE as social goods, the major question associated is financing. How it is financing in federal republic country like Nepal and whom it serves. How it creates the positive impact for the prosperity of Nation? What are the international trends of financing higher education? Are HEIs especially Community campuses the result of societal needs or wants of some professionals associated with it? How is it social entrepreneur?

High students enrollment, high dropout, poor results, low salary to faculties and associated, curricula and extracurricular activities, infrastructure, academic calendar, examination system, subsidy policy, research and collaboration, leadership of HEIs, accountability, etc are some of the areas where reforms are urgent. Besides, Nepal is facing the problem of brain drain, equitable access, equity in opportunity, quality, relevancy, employment, and many others. Each government has adopted an approach of laissez fairyism- non-intervention policy in HE sector. But still the system is running with their executive orders. Currently, the Vice-chancellor of Nepal Sanskrit University was not allowed due to different ideological causes to participate in international conference and trapped from airport by violating the autonomy of university act. Which was big political interference from democratic government (Wagle, 10 $0^{\text {th }}$ July 2018). Government has fix solutions which suffer from lack of coherence and consistence in approach, and hampering the long term perspective of higher education. Hence as a result, Government's ability to control and confined education to its borders is fast eroding.

Higher Education in Nepal is in the phase of re-engineering and re-building process which needs a lots of investment to raise its quality, access, equity efficiency and good governance in this sector. There are three types of higher education institutions (HEIs) in Nepal; constituent, community and private campuses of universities. Currently, there are 11 universities in Nepal along with four autonomous medical institutions (UGC, monitoring division, 2018). All the universities have been established to meet some specific purpose through separate university act to fulfill the needs of HE. All the universities have been seemed to replicate the affiliating model of TU. 
Declining education budget although the figure is increasing, discrimination in disbursement of public fund, student fees, not equitable access, low quality and relevance of conventional disciplines like Education, Management, Humanities, and Laws are lacking its importance due to limited job scope. Besides low scholarship schemes for the weaker section of the country and weak provision of student loan are some of the issues. Quality erosion, infrastructure development, and high political intervention and diminishing public investment in higher education are some of the major challenges. Currently, the burden of HE has been shared to the provincial government and basic and secondary level education to the local level government. Likewise, the central government has the responsibility to finance the central universities (Constitution of Nepal, 2015).Some province has allocated budget for the development of higher education in their province too. The attempt has been made to answers of above questions through this paper.

\section{Objectives}

The main objectives of this paper were to explore the public financing in HE for the sustainability, access, equity and quality. The specific objectives were as follows

- To explore the role of higher education institutions in the development of higher education in Nepal

- To investigate the trend of public financing with references to access, equity, quality.

- To point out some issues and challenges in higher education financing sector.

\section{Methods and materials}

A mixed method approach (Qualitative as well as the Quantitative) has been adopted to conduct this research. Both primary and secondary data were used. The primary data were purposively collected from the participants (Campus Chief/ Chairman/ President of PCS) in a gathering organized by Nepal Public Campus Sangh in all province for the purpose of collecting problems, issues and challenges of HEIs specially community campuses. The researcher raised the problems and issues faced by community campuses to collect their feedbacks and suggestions. Discussions were made with focused group to collect the views, notions and feedbacks and also incorporated in the seminar report submitted and presented to the faculty of education, graduate school of education, TU for the partial fulfillment of the Degree of Philosophy in Education. 


\section{Results and discussion}

This part discussed mainly the growth of higher education institutions, equity, relevancy, public financing, expenditure trends, issues, challenges and conclusions.

\section{Historical prospective}

The post-1950 period was presented by the government in Nepal as a time of opening up to the outside world as education was confined with the high caste groups, with opportunities to gain education and employment in the civil service dependent on family and caste ties with the Rana elite (Caddel, 2007). With the recognition of education as the keystone of democracy, the Government of Nepal established an Education Board in 1952 AD to supervise and expand the existing educational facilities(NESP, 1956). In the early1950's, educational systems of the world over began a process of expansion without precedent in human history. "Student enrollments more than doubled in many places, expenditures on education rose at an even faster rate, and education emerged as the largest local industry" (Coombs, 1968, p.1). But in early 1950 's, the access to education in Nepal was not as mentioned by Coombs, rather it was confined to few classes of so called higher, socio-economic status group of Rana regime.

The formation of the National Education Planning Commission(NEPC) in 1953 was a landmark in the educational development of Nepal.The Commission recommended to charge a modest tuition fees for messing, lodging and bearing at least one tenth operating cost of HE. The remaining funds should come from the general treasury as part of the annual budget and through people participation focused on secure donations for scholarships and student loan, land and building for university, collection of books from public for central library. Moreover, it also suggested to assist the deserving and needy students by providing partial and full scholarship and part time employment to finance their own expenses (NESP, 1956, p.p136-137). Since then a number of boards, commissions, committees and plans have been formed for the development to reform the national education system.

National education system plan for (1971-76) was prepared in the command of late King Mahendra in consonance with the requirements of the Panchayat System polity with the very aim to save the Monarchy and Crown as well as to produce the manpower dedicated to Panchayat System (MOE,1971). As a consequence, no other institutions were granted permission to provide HE, one year field work was made compulsory and about (25 to 50) percent of costs besides other expenses in HE was bearded by the government (MOE, 1971). 
Students' agitation started in 1980AD, with the agendas of educational and political reform in the country. The government and the TU could not control the agitation, and to pacify this, the late King Birendra formed a commission on HE in 1980, which brought the concept of multi-universities; private and community colleges was allowed to be run again in the country (Bhattrai, 2014). The popular expectation of quantitative and qualitative extension of education necessitates a rising level of governmental investment. The private sector was encouraged to establish educational institutions to run different courses (NEC, 1992).

NEC-1992 was private friendly policy document and was therefore opened the door of private investment in education. Numbers of schools as well as the colleges were established with the view of profit making. The discrimination in education had been started with the name of liberation, privatization and globalization. Finally education belongs to the hand of businessman and created classes in the Nepalese society. It was an unusual policy crisis which was continued after the re-establishment of democracy in 2046 BS. After 1996 to 2006, it was the time of conflict popularly known as people war. Maoists and security forces had been destroying the educational sectors for the last ten years with a loss of human life (Himalayan News Service, Published: 9 July, 2005).

After the declaration Nepal as a federal, democratic, republican country, the aspirations for sustainable peace, good governance, development and prosperity is the constitutional commitment. To fulfill this commitment, the big question raises associated with the finance of higher education.

\section{Higher education and literacy rate}

According to Central Bureau of Statistics, the overall literacy rate (for population aged 5 years and above) has increased from 54.1 percent in 2001 to 65.9 percent in 2011. Male literacy rate is $75.1 \%$ compared to female literacy rate of $57.4 \%$ (CBS, 2011). The vast majority $95.2 \%$ male and $97.37 \%$ female are still out of the access of HE in Nepal.

\section{Growth of HEIs}

Nepal's HE system is different from many other countries of the world in the sense that it comprises public, community and private sectors. Between 1991 and 2013, student enrolments in HE increased by more than 600 percent ( 7 times), and number of HEIs increased by 540 percent (6.4 times, Bhatta, 2015). The following chart shows the current status of HEIs in Nepal. 


\section{Figure 1. The current status of HEIs in Nepal}

HEls in Nepal-2016

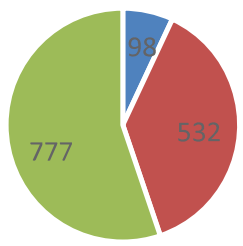

- Constituent community - Private

This pie chart reveals that there were 1407 HEIs in Nepal affiliating under different 11 universities. The composition of constituent, community and private HEIs are 98, 532 and 777 respectively.

Source: UGC-EMIS(2015/16)

\section{Trend of higher education}

In June 2017, the British Council released a report illuminating 10 trends in global higher education that impact the future of internationalization. While the report is written from a UK perspective, the findings can be applied widely. The report focuses on Shifting global demographics, expansion of education for all, National internationalization strategies, distribution of national funding, multi-sector cooperation, educational technology, demand for specific skills, brand and value, impact of English, and focus on the student experience and labour market demands as just a few of the issues impacting the internationalization of higher education (BC,2017).

Table 1: Total number of students in different FY

\begin{tabular}{cccccc}
\hline Type of Campus & $2015 / 16$ & $2014 / 15$ & $2013 / 14$ & $2012 / 13$ & $2011 / 12$ \\
Constituent & 121772 & 127964 & 144008 & 209893 & 157561 \\
Community & 110895 & 128853 & 150344 & 172095 & 150167 \\
Private & 128410 & 151087 & 164269 & 187677 & 137266 \\
Total & 361077 & 407904 & 458621 & 569665 & 444994 \\
\hline
\end{tabular}

Source: UGC-EMIS, (2011/12 to 2015/16)

The table reveals that, the student enrollment in higher education institutions are decreasing gradually except 2012/13.

Table 2: Share of students (\%) in different FY

\begin{tabular}{cccccc}
\hline Type of Campus & \multicolumn{5}{c}{ Fiscal Year } \\
& $2015 / 16$ & $2014 / 15$ & $2013 / 14$ & $2012 / 13$ & $2011 / 12$ \\
Constituent & 33.72 & 31.37 & 31.40 & 36.84 & 35.41 \\
Community & 30.71 & 31.59 & 32.78 & 30.21 & 33.75 \\
Private & 35.56 & 37.04 & 35.82 & 32.95 & 30.85 \\
\hline
\end{tabular}

Source: UGC-EMIS, (2011/12 to 2015/16) 
The table reveals that, the average student enrollment in Constituent, Community, Private higher education institutions in different fiscal year are $33.74 \%, 31.8 \%$ and $34.4 \%$ respectively. This shows that the contribution of private colleges are higher than others.

\section{Inclusion in higher education}

Equal access to an opportunity for marginalized and disadvantage group of the society is the core concern of federal Nepal as it has been proclaimed in the constitution. In the constitution 2015, it has mentioned in article 31(4) "The citizens with disabilities and the economically indigent citizens shall have the right to get free higher education in accordance with law". Likewise in the policy of Higher Education-2015, reveals "For the access and continuation of HE, the government will support the indigenous people". Dalits, Madhesi, differentlyable, poor, economic backward and disadvantage as well as the marginalized group of people are living in difficult geographical region but opportunity continues to be disproportionately distributed.

The situation of the Madhesi Dalits in the core areas of Plan operations is still worse off than the rest including the Dalits from other settlements in spite of continued Plan interventions in the Madhesi Dalits areas, which is indicative of the deep rootedness of the social exclusion of the Madhesi Dalits (Plan Nepal, 2008). To remove inequality, discrimination and exclusion from Nepalese society "egalitarian, equity and reservation are essential things. To do these things, some radical changes will have to be done in political system especially focusing on model of representation P.R. from F.P.T.P., division of quotas in entry gate of bureaucracy, educational institutions, science and technology, security forces, planning mechanism, judiciary and each and every organ of the state", (Prasai, 2018, p.3).

We have persistent gaps in education, income, and wealth, and these gaps are widening as our nation becomes more diverse. As a result, the middle class is shrinking, and the fastest-growing segments of our population are the least likely to have the opportunities they need to succeed. The slogan prosperity in Nepal cannot thrive unless all Nepalese are fully empowered and prepared to contribute to our economy and engage effectively in federalism. And that means restoring the middle-class. Today, wellpaying, low-skill jobs are disappearing, and in turn, Nepal's economic polarization is increasing. After the declaration Nepal as a federal republic, the composition of HEIs in each province are not accessible. Currently, Province three has the maximum number $612(43 \%)$ of HEIs where as in six, it is very low i.e. $56(4 \%)$.Geographically,the share of HE in Hilly region, Himalayan region and Terai region are 59\%,5\% and $36 \%$ respectively( UGC-EMIS-2015/016). 


\section{Equity in higher education}

Equality is about uniformity; it focuses on making sure everyone gets the same thing. Equity is about fairness; it ensures that each person gets what he or she needs. This distinction is especially important in education, where there are visible gaps in opportunities and outcomes for large numbers of students. Historically, low-income students and students from Terai especially Madhesi have been excluded from too many opportunities including higher education.

To effectively educate today's students, HE must focus on both equity and quality to make the most empowering forms of higher studies available to all students. Equity refers to the effects of a public policy on the fairness of the distribution of benefits and costs to higher education.

\section{Gender parity}

The gender parity rate in higher education has been mentioned in the table below.

Figure 2: Gender parity in higher education

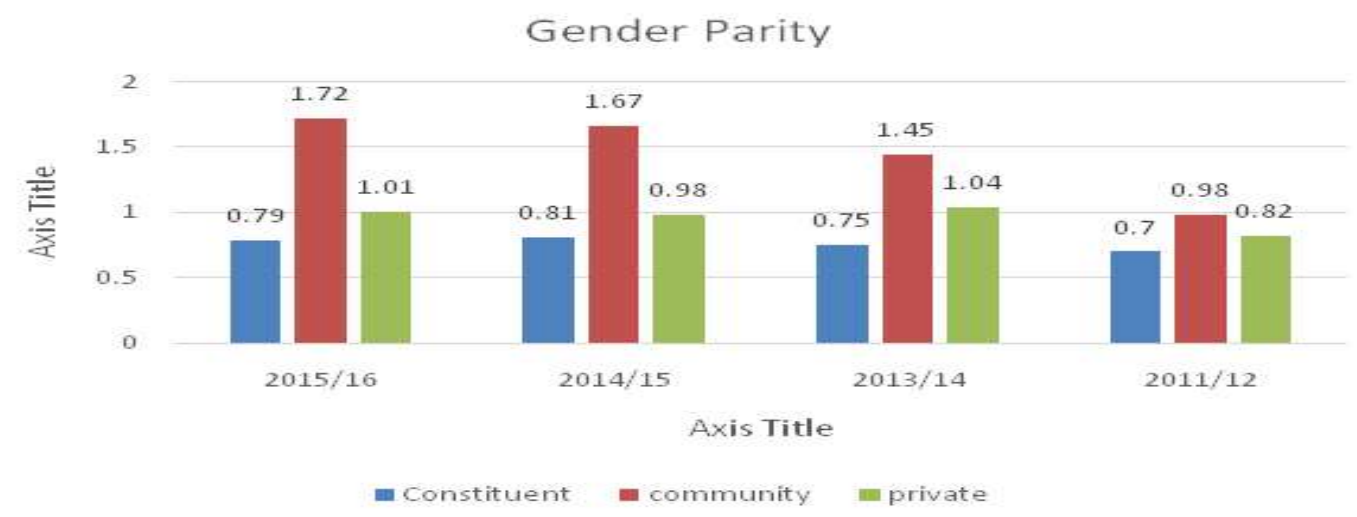

Source: UGC-EMIS (2015/16).

This chart shows that the Community Campuses is the choice of low-income students, dalits and women's disproportionately attend community colleges. While the gender parity rate for girls and women are relatively low in constituent campuses where as private campuses is the equal access to the girls and boys. The belief of girls and women seems to be almost double in community campuses.

\section{Disability}

About two percent $(1.94 \% ; 513,321)$ of the total population reported to have some kind of disability, most of them are deprived to get the access of higher education.

\section{Higher education reform project-rhetoric versus reality}

The reform in higher education has no long history in Nepal. The first higher education project was started in 2050 with the initiation of TU. The second higher 
education project was initiated with the efforts of University Grants Commission form (2007-2014). With the experiences and challenges of the reform projects, with the great hope and aspiration and demand of quality education the Higher Education Reform Project (HERP) was formally started in 22 May 2015 to achieve the baseline targets relating to the disbursements linked indicators. The table below shows the participation of Higher education institutions in HERP.

Table3: Participation of Higher education Institutions in the HERP (2015-2020)

\begin{tabular}{lcc}
\hline \multicolumn{1}{c}{ Participated HEIs } & Number & Percent \\
Community Campuses & 124 & 68.13 \\
Constituent and Autonomous of TU & 30 & 16.48 \\
Central Department- Central Campus & 13 & 7.14 \\
KU- Campuses & 7 & 3.85 \\
PoKU- Campuses & 4 & 2.20 \\
PU-Campuses & 4 & 2.20 \\
Total HEIs & 182 & 100.00 \\
\hline
\end{tabular}

Source: (UGC, HERP-11, June- 2018 personal conversation ).

According to aforementioned data the participation of community campuses are highly remarkable. Around 68 percent among the participants belongs to the community campuses. But the reality of financing as per the claimed of UGC has not been subsidized to the community campuses. A gathering of Campuses Chiefs, Chairman of the Campus Management Committee and the President of Nepal Public Campus Sangh Campus Unit related with the community campuses held in all seven province in FY 2017/18 raised some questions regarding the achievement of target which are not visible in reality as its claimed. TU and other Universities are not maintaining the academic calendar, not publishing the annual and semester examination results in timely manner, weak disseminations of performance based funding(PBF)and formula based funding $(\mathrm{FBF})$ and miss interpretation of public procurement act by the concerned authorities of UGC to its stakeholders, It has created confusion in utilizing its matching grants, the funds that needs to be reviewed from new perspective which should be justifiable for the major stakeholders of the reform project to convert rhetoric into the reality.

\section{Higher education and QAA process}

The University Grants Commission Nepal has set a target to accredit 125 HEI within the Higher Education Reform Project period (2015-2020) to ensure quality higher education in Nepal. In order to ameliorate the QAA system making it more credible with independent assessment and accreditation, UGC has strengthened the capacity of the division towards making it function as an autonomous unit. 
According to the QAA Division, 18 out of total 22 HEIs accredited, are community campuses. In a total of 19 peer -visit completed for the same purpose, a majority 17 are community campuses. As per the cycle of the formation of peer reviewed team is concerned, out of total 13 PRT formed, 10 HEIs are from community campuses. HERP has targeted 125 HEIs for QAA certification with in the project period. Due to the slow growth rate of accreditation process, it has been limited up to 60 HEIs (HERP Unit and QAA Division, 2018).

\section{Public financing in higher education}

Government of Nepal has adopted the cost recovery policy since the Ninth Five Year Plan, 1997-2002 to reduce the burden of higher education on the national coffer (NPC 1998). For the disbursement of public fund in the higher education institutions, UGC was formed in 1995 with specific objectives and functions. UGC Nepal has recently formed a High Level Committee for the intensive study of the structure, governance and financing of higher education as per the federal structure of the country (UGC, 2017).

UGC board has approved the budget and programs for the fiscal year 2017/18 with the total amount of Rs. 9.917915 billon for the operation and capital development of HE sector. Out of this budget, Rs 1.823 billion has been allocated for the capital development of HEIS in the country. It is $18.36 \%$ of the total budget while $81.63 \%$ has been allocated for the operation. Rs. 6.645 billion has been allocated for TU, which amounts to $67 \%$ of the total HE budget. The Commission has also allocated Rs. 0.65 billion for regular and physical facility development grants to community colleges across the country. Likewise, UGC has approved the different programs and activities under the Higher Education Reform Project (HERP) with the estimated cost of Rs. 0.9974 billion for the fiscal year 2017/18. The aim of this project is to support reforms in the selected institutions for improving the quality, relevance and efficiency of HE and to assist underprivileged students for equitable access to higher education. The total cost of the project is NRs. 6.5 billion (UGC, 2017).

The UGC budget 2074/75 also discussed the per student public financing in HEIs. As per the data, per student expenditure in Lumbani Boudha University with 196 students is 586.73 thousands is higher than the others. Similarly, per student cost in TU is 38.29 thousands. The university having less students was found higher per student costs.

\section{Annual growth rate and higher education}

The annual growth rate of Nepal is very less in comparison to the South Asian countries. Unsuitability, conflict,general election and corruption were the major causes. 
The figure below shows the annual growth rate in different FY.

Figure 3: Nepal GDP Annual Growth Rate (2000-2018)

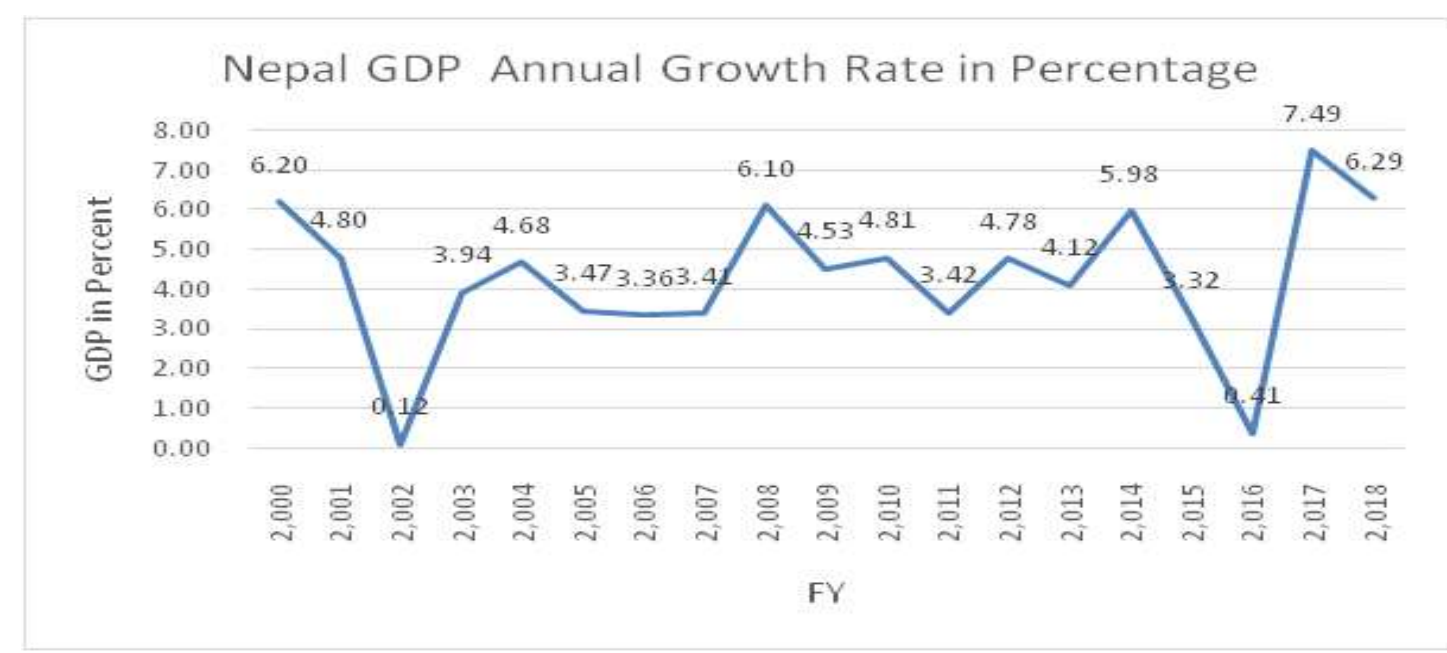

Source: https://data.worldbank.org/indicator/NY.GDP.MKTP.KD.ZG

The government of Nepal has made a commitment in diffident international forum to invest up to $5 \%$ of GDP in higher education but in practices it is less than $3 \%$ only. National trend of public expenditure in education

The national trend of financing higher education is decreasing each year. In 1990 ithe public financing was around $20 \%$ of total national budget but in the current FY it was only 10.2 percent. The figure below shows the financing trend of education in Nepal.

Figure 4: Share of different year educational budget in percentage

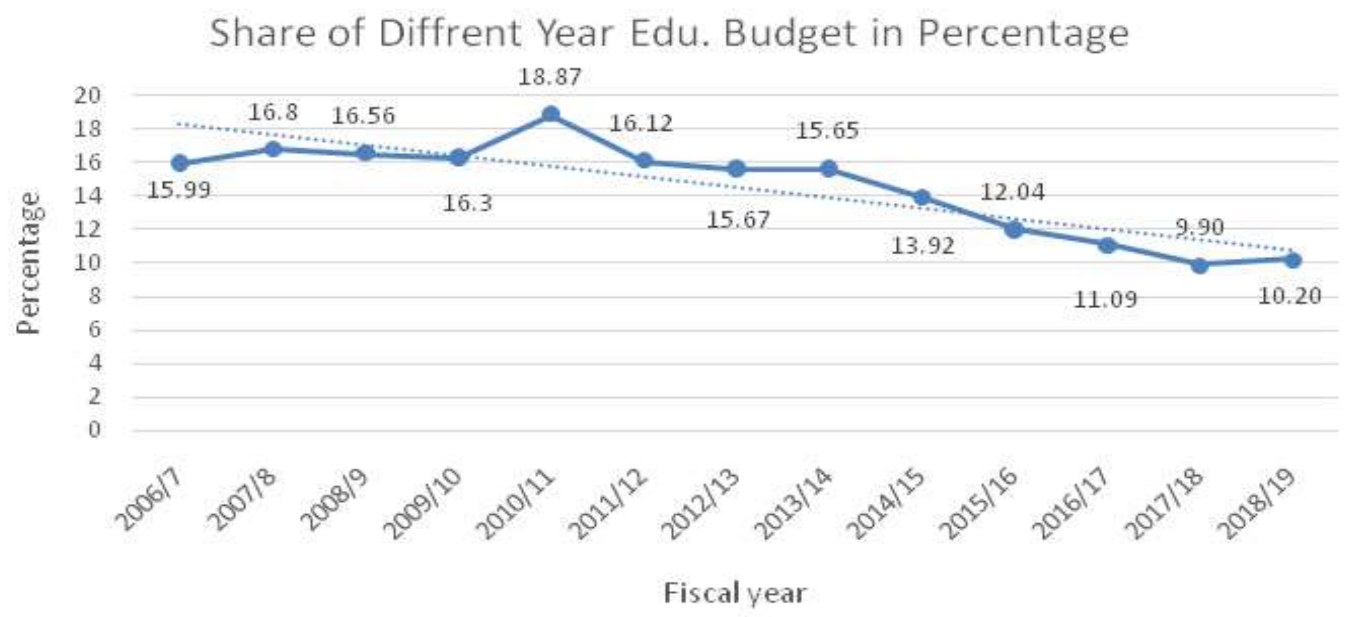

Source: UGC, EMIS Various Years and Teachers Monthly Magazine (June, 20218) 
Education sector of Nepal has received its lowest share of $10.2 \%$ budget in current Fiscal Year. Though the volume of budget of the government and its share is increasing, but in reality, the total percentage contribution in education is decreasing. This shows the fact that the priority of government towards education sector is in the decreasing trend.

\section{Trend of public expenditure in higher education}

Public financing to community HEIs in Nepal is no longer. With the advancement of democracy in Nepal, UGC started to finance community campuses to nominal grants. The following figure shows the trend of public financing to the community campuses in different FY.

Figure 5: Public financing in higher education in different year percentage.

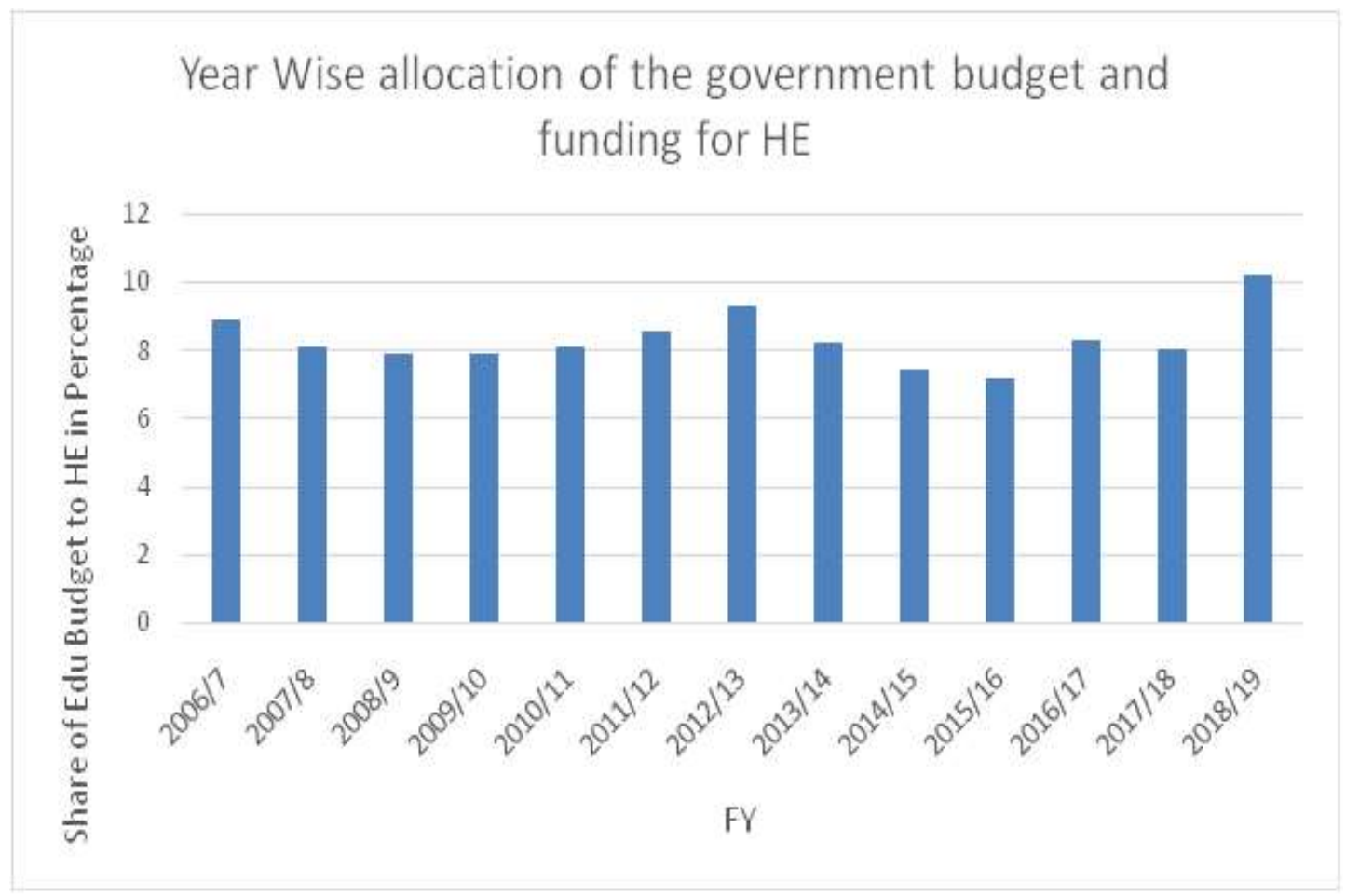

Source: UGC, annual report (2006-2019)

The figure above shows that the average budget allocation in higher education are $8.35 \%$ of total higher education budget. 


\section{Trend of public expenditure in community campuses}

Financing of community campuses was started from 2051 BS. Initially it was financed with the name of private campuses and latter it seemed to be finance with the name of affiliated campuses. Since 2053 BS, UGC recognized these affiliated campuses as the community campus. In the beginning, UGC allocated 10 million ( Rs One crore Nepalese currency).Gradually the numerical figures of investment had been increasing but currently it has been constant as an average investment $6.28 \%$ of the total higher education budget. The figure below shows the trend of financing community campuses in Nepal.

\section{Figure 6: Trend of public financing in community campuses.}

\section{Share of $\mathrm{HE}$ budget in Community Campuses in \%}

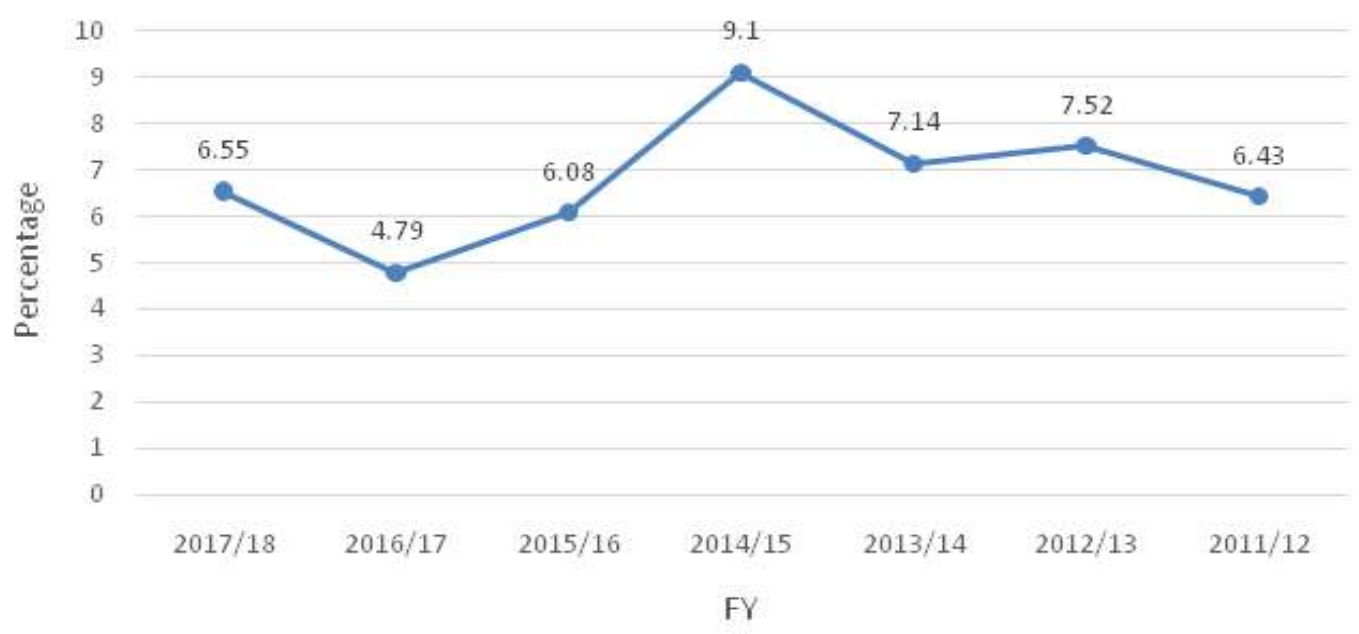

Source: UGC annual report (2012-2018)

This figure shows the trend of public investment is increasing but the share of higher education budget to the community campuses are almost constant which ranges minimum 6 to 9 percent of the total higher education budget.

\section{Issues and challenges of higher education}

Nepal is facing the critical issues in the development of HE are (i) the over rapid expansion of enrollment; (ii) the under-financing of the higher education system; (iii) the low level of managerial effectiveness; and (IV) quality erosion. 


\section{Funding of higher education}

The proportion of the education budget allocated to higher education has been declining each year, which hampers the quality, accessibility and relevancy.

The proportion of government budget allocated for HE is presently about $10.2 \%$. HEIs need more resources to undertake quality improvement programs. HEIs should explore other resources to meet its regular and capital expenses as well.

\section{Enhance the quality of education}

The problem of low quality of education in the higher education institutions has been the critical issues in HE. The goal set is to raise the standards to international levels. This will require provision of sufficient facilities, dedicated teachers, highly motivated students and access to high quality learning resources.

\section{Financing modality}

Concrete policy has been framed on the financing of higher education institutions to make higher education accessible, quality, relevance and uplift the standard to the disadvantage group and a financial weaker people. Public has been providing the land, building and other donations to the community campuses but government and its agencies are not encouraging the efforts of the community people to reduce the burden of higher education on the national coffer.

The participation of the community campuses in higher education has been a remarkable feature in recent years. But the trend of financing is still based on the formula funding designed for community campuses. This is the hindrance for the development of HE.

\section{Access to higher education}

Access of girl students to higher education is very poor; it has to be increased by enhancing community campuses. Poor, brilliant and needy students from the marginalized, dalit and janjati groups should be encouraged to acquire higher education for social and economic justice without this a dream of new Nepal is not possible. Access is limited with the gross enrollment ratio of about 6\% (Aryal, 2005).

\section{Equity}

Currently higher education enrollment is expanding primarily in the private sector. This is likely to restrict even more the access to higher education for poor segments of the population (Aryal, 2005). 


\section{Quality and relevance}

Collaboration between employers and academic institutions is weak, and so is the research and development in these institutions. As result, barring few premiere institutions the relevance of higher education to the job market needs is poor (Aryal, 2005).

\section{Governance in HEIs}

Although Nepal has initiated the process of decentralization as a means of improving governance, overall the governance of public higher education is still weak (Aryal, 2005).

\section{Higher education policy}

Nepal needs a HE Policy that can address the current challenges of the higher education. The proposed higher education policy (HEP) document has focused on the external governance of HEIs and is mostly silent on issues related to their internal governance. The creation of many mechanisms to externally govern HE will further centralize the governance of HEIs is challenge to federal Nepal. If the proposed HEP is implemented, at least 10 central level commissions, boards and committees will be formed.

\section{High political intervention}

From the beginning, education decisions specially financing in education were political decisions and certainly not the decisions of the technical experts. The political economy of education has remained a dominating factor in determining educational policies and programs. In the name of reforms in education, commissions were formed in the past and the scenario is not different till now. Every commission presented a model based on sound technical, pedagogical and ethical principles as well as on the basis of their terms of references. However, every decision on the model was made by the political leaders. The Nepalese education system drives its political legitimacy. Currently, no national as well as the regional political parties really applied its mind to the educational problems and issues deeply and formulated well-conceived long term policies of its own. Each political party has its own ideological organizations but the interaction between the political leaders and educationists on current educational issues are rare. Ideological organizations are working to safe guard the benefits of their members and seemed less involved for the sustainable development. Without sound financing, the slogan of prosperity is difficult to achieve as higher education is only the means to change the life style and overcome the poverty to sustain the political development progress of the nation. 


\section{Conclusion}

Nepal has achieved remarkable progress in the development of HE since early 1970s when the Government started to implement the NESP, the university is facing increasing financial constraints, managerial problems and quality deterioration in teaching and learning. Currently, Nepal is facing the critical issues in the development of $\mathrm{HE}$ are (i) the over rapid expansion of enrollment; (ii) the under-financing of the higher education system; (iii) the low level of managerial effectiveness; and (IV) quality erosion.

To improve the HE in Nepal, the role of UGC has to be redefined in the federal Nepal. The UGC has endorsed the HE policy formula based funding to the HEIs specially universities of Nepal.

To promote the accredited HEIs the provision ofQuality Assurance and Accreditation (QAA) has fully in operation. Out of total 1407, HEIs, 20 have been accredited and 101 are in pipeline. 17 of them are community campuses. UGC has prepared the National Priority areas and prepared and linked to research funding, establishing new institutions and other funding. Besides, Higher Education Reform Project (HERP) initiated. These are some of the major achievements of HE in Nepal. Besides these achievements, some major hindrance as the access to HE, quality, equity in access and quality, relevancy, lack of students supports, equity in faculty development and empowerment, less than 1.21 percent financing to $\mathrm{HE}$ in comparison to national budget where the demand of $\mathrm{HE}$ is high.

Education sector of Nepal has received its lowest share of $10.2 \%$ current year budget. Though the volume of budget of the government and its share is increasing, but in reality, the total percentage contribution in education is decreasing. This shows the fact that the priority of government towards education sector is in the decreasing trend.

\section{References}

Aryal, M.P. (2005). Higher and Higher Secondary Education in Nepal. Kathmandu, Nepal

Bhatta, P. (2015). Retrieved from: www.martinchautari.org.np/files/SINHAS./SINHASVol.20-No.2_Pramod-Bhatta.pd

Bhattrai, K.P. (2014) Higher education in Nepal; Truth and Challenges - Civil Initiative civilinitiative.org/254/retrieved from http://Civil initiative.org/254 on June 10,2018. http://www.unesco.org/education/nfsunesco/pdf/COOMBS_E.PDF 
British Council (2017). Megatrends: The future of international education in 2013. Retrieved from https://ei.britishcouncil.org/educationintelligence/10-trends-transformativechanges-higher-education.

Coombs, Philip, H. (1968). The world educational crisis: A system analysis; New York: Oxford University Press.

Government of Nepal (2015). Constitution of Nepal (2015). Kathmandu: Authors.

His Majesty's Government of Nepal (2001). Report of high level task force on education. Kathmandu: Ministry of Education and Sports.

Jandhyala, B.G. Tilak (2015). Higher Education in South Asia: Crisis and Challenges Social Scientist, Vol. 43, No. 1/2 (January-February 2015), pp. 43-59 retrieved from URL: http:// www.jstor.org/stable/ 24372963 Accessed: 10-05-2017 19:07 UTC.

M, Caddell, (2007). Education and Change: A historical perspective on schooling, development and the Nepali Nation-State. Retrieved from https://pdfs. semanticscholar.org/d828/e7e6d8be17623ccfff54aa8a19e95ce1cbd0.pdf

Ministry of education (1971). The national education system plan for (1971/76). Kathmandu: Author.

MoES, (2006). Nepal in Educational Figures, Ministry of Education and Sports. Kathmandu: Nepal.

National Education Commission (1992). Report of the national education commission. Keshar Mahal, Kathmandu, Nepal.

Plan Nepal (2008). Final Evaluation of Inclusion of Dalit and People with Disability Project. Reatirved from https://norad.no/om-bistand/publikasjon/ngo-evaluations/2009/finalevaluation-of-inclusion-of-dalit-and-people-with-disability-project/

Prasai, D.R. (2018). Issues of Reservation and Affirmative Action for Minorities in Nepal an Anthropological Review, Retrieved from file:///C:/Users/user/Downloads/17148-563491-SM.pdf

The National Education Planning Commission (NESP), (1956). Education in Nepal. The bureau of Publications College of education Kathmandu, Nepal

The Himalayan Times (2005). Effect of conflict on education discussed.Pokhara.Retairved from https://thehimalayantimes.com/nepal/effect-of-conflict-on-education-discussed/

University Grants Commission (UGC) (2015-16). Educational Management Information System: Annual Report, (2015/16) (Kathmandu, Nepal). 
UGC (2014-15). Educational Management Information System: Annual Report, (2015/16) (Kathmandu, Nepal).

UGC (2013-14). Educational Management Information System: Annual Report, (2015/16) (Kathmandu, Nepal).

UGC (2012-13). Educational Management Information System: Annual Report, (2015/16) (Kathmandu, Nepal).

UGC (2011-12). Educational Management Information System: Annual Report, (2015/16) (Kathmandu, Nepal).

UGC (2017). A Bi-monthly newsletter of University Grants Commission (UGC), Nepal Volume 6, Issue 1 (Shrawan-Kartik, 2074) 2017.

UGC (2015). Report on achievement of disbursement linked indicators for HERP Year (2014/15). Author

United Nations Educational, Scientific and Cultural Organization (UNESCO) Institute for Statistics. (2017). Expenditure on tertiary education (\% of government expenditure on education).

UNESCO (2014). A resource materials on education and federalism in Nepal: Aasaman Nepal, Sanepa-2, Lalitpur.

Wagle, M.P. (2018). Autonomy of higher education. Kantipur Daily, July 102018.

Williams, G. (2016). Higher education: Public good or private commodity? : London Review of Education DOI: 10.18546/LRE.14.1.12 Volume 14, Number 1, April 2016.

World Bank (2018). https://data.World Bank. Org/indicator/SE.XPD.TERT.ZS. Retrieved in 9 july 2018 